\title{
蛋白质分子理性设计与肌红蛋白功能的调控 及拓展
}

\author{
林英武 ${ }^{(1)}$ ，王江云 ${ }^{(2) *}$, 陆艺 ${ }^{(3)}$ \\ (1) 南华大学化学化工学院, 衡阳 421001, 中国 \\ (2) 中国科学院生物物理研究所非编码核酸重点实验室, 北京 100101, 中国 \\ (3) 伊利诺伊大学厄本那-香槟分校化学系, 伊利诺伊 61801, 美国 \\ *通讯作者, E-mail: ywlin@usc.edu.cn; jwang@ibp.ac.cn; yi-lu@illinois.edu
}

收稿日期: 2013-11-15; 接受日期: 2013-11-27

全文见: Lin YW, Wang JY, Lu Y. Functional tuning and expanding of myoglobin by rational protein design. Sci China Chem, 2014, 57(3): 346-355

doi: $10.1007 / \mathrm{s} 11426-014-5063-5$

\begin{abstract}
摘要蛋白质分子理性设计, 不但对于揭示天然金属蛋白的结构与功能关系, 而且对于创造具有性质和功能 改善的人工金属蛋白, 都是一个功能强大的策略. 肌红蛋白(myoglobin, Mb), 自然界创造的一种具有多重生物 功能的血红素蛋白, 已被证明是蛋白质分子理性设计的理想框架. 本文主要综述了两个方面, 一是对其天然的 氧结合与运输、过氧化物酶(peroxidase)和亚硝酸盐还原酶(nitrite reductase, NIR)的功能进行调控, 二是将其功能 理性拓展到过氧酶(peroxygenase)、血红素-铜氧化酶(heme-copper oxidase, HCO)、一氧化氮还原酶(nitric oxide reductase, NOR)和羟胺还原酶(hydroxylamine reductase)等. 这些研究加深了我们对自然界金属蛋白如何工作的 理解，也为将来具有实际应用前景的功能金属蛋白的理性分子设计提供了线索.
\end{abstract}

\section{关键词金属蛋白 血红素蛋白 蛋白质分子设计 氧化酶 还原酶}

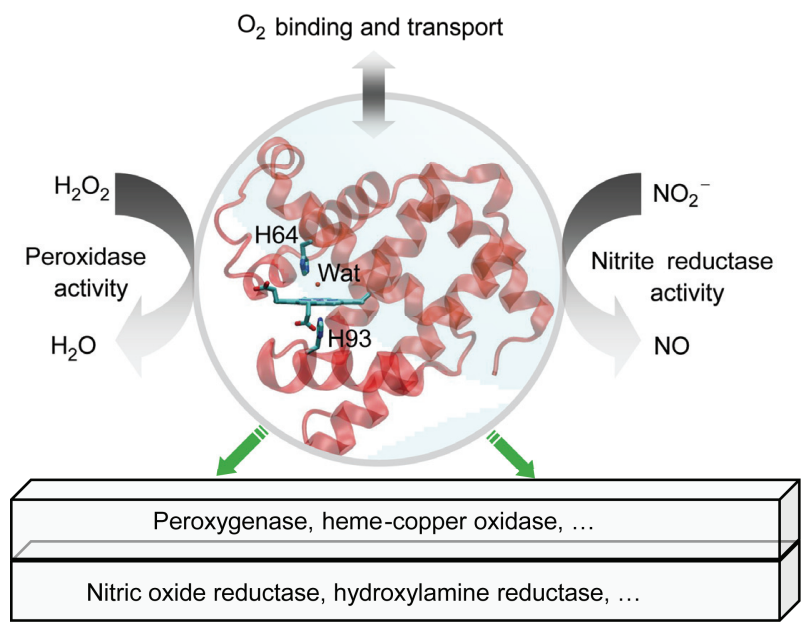

Rational protein design using $\mathrm{Mb}$ as a scaffold by functional tuning and expanding. 